Tropical Journal of Pharmaceutical Research September 2017; 16 (9): 2055

ISSN: $1596-5996$ (print); 1596-9827 (electronic) (c) Pharmacotherapy Group, Faculty of Pharmacy, University of Benin, Benin City, 300001 Nigeria.

All rights reserved.

\title{
Erratum for "Protective role of allicin (diallyl thiosulfinate) on cell surface glycoconjugate moieties in 7,12- dimethylbenz(a) anthracene-induced oral carcinogenesis"
}

\section{Sasikumar Dhanarasu ${ }^{1}$ and Samir Qiblawi ${ }^{2}$}

${ }^{1}$ Department of Biochemistry, ${ }^{2}$ Department of Histology, College of Medicine, University of Hail, PO Box 2440, Hail, Kingdom of Saudi Arabia

*For correspondence: Email: drdskumar31@yahoo.com; Tel: +966-535461930

Revised accepted: 20 April 2017

\section{Erratum}

Jin et al Trop J Pharm Res 2017, 16(8): 1797-1804 http://dx.doi.org/10.4314/tjpr.v16i8.7

The name and address of the second author, Samir Qiblawi, were inadvertently omitted in earlier published article.

Citation: Dhanarasu S, Qiblawi S. Protective role of allicin (diallyl thiosulfinate) on cell surface glycoconjugate moieties in 7,12-dimethylbenz(a) anthracene-induced oral carcinogenesis. Trop J Pharm Res 2017; 16(8):1797-1804 Erratum: 2017; 16(9):2055 http://dx.doi.org/10.4314/tjpr.v16i9.3

Tropical Journal of Pharmaceutical Research is indexed by Science Citation Index (SciSearch), Scopus, International Pharmaceutical Abstract, Chemical Abstracts, Embase, Index Copernicus, EBSCO, African Index Medicus, JournalSeek, Journal Citation Reports/Science Edition, Directory of Open Access Journals (DOAJ), African Journal Online, Bioline International, Open-J-Gate and Pharmacy Abstracts 